\title{
KNOWLEDGE MANAGEMENT LIFECYCLE AND ORGANISATIONAL DECISION MAKING OF PAINT MANUFACTURING COMPANIES IN RIVERS STATE, NIGERIA
}

\author{
EDEBIRI, Odiri S. \& BESTMAN, Anthonia E. (Ph.D.) \\ Department of Office and Information Management, \\ Faculty of Management Sciences, \\ Rivers State University, Port Harcourt, Nigeria.
}

\begin{abstract}
This study investigated the influence ofknowledge management lifecycle on organisational decision making of paint manufacturing companies in Rivers State. The study was operationalized with the dimensions of knowledge management lifecycle as knowledge identification, knowledge creation, knowledge storage and knowledge transfer. Organizational decision making was measured by timeliness and cost effectiveness. The target population of this study is all 51 registered paint manufacturing companies in Rivers State. Purposive sampling was used to select a sample of 90 respondents from 30 selected manufacturing companies in Rivers State. The study used cross-sectional survey approach and descriptive research design.The study was guided by five research questions and ten research hypotheses. Questionnaires were the major instrument used in gathering primary data which were analyzed using correlational analyses. The questionnaire used was subjected to face/content validity, this was done to ascertain the validity of the questionnaires to be administered. The scale used for this study had been previously adjudged reliable. However, we also checked by verifying reliability outcomes through confirmatory test of internal consistency on the instrument with our sample using Cronbach alpha at the threshold level 0.7 which is generally accepted by the rule of thumb. Data was analyzed and results presented in tables, mean and standard deviation. And, finally hypotheses were tested using the Spearman Rank Order Correlation Coefficient. The study found that knowledge management lifecycle significantly impact on organisational decision making. The study recommends that in order for paint manufacturing companies in Rivers State to maintain their hedge in this high rivalry economy, they should pay more attention to how knowledge within the organisation are effectively managed as this will facilitate an effective time management and cost optimisation within the organisation.
\end{abstract}

Key words: Knowledge Management, Knowledge Identification, Knowledge Creation, Organisational Decision-Making, Timeliness, Cost Optimization 


\section{INTRODUCTION}

Knowledge is one of the most important assets that guarantee the survival of companies in the fiercely competitive business space. The emergence of knowledge-based economy has made it important necessity for businesses to initiate ways to effectively acquire and manage changing organizational knowledge. Knowledge when produced and disseminated all over the company has the capability to contribute to the firm's value (Choi, Lee, Han, Baik, Song, Lim \& Lee, 2006). Ineffectiveness in managing knowledge makes the knowledge irrelevant and not useful for organizations (Yusof and Abu Bakar, 2012). Hence, Knowledge Management (KM) is considered to be an urgent and critical issue, to such an extent that companies must efficiently manage their knowledge bases and sources to earn long-term competitive advantage (Sarkindaji, Hashim,\& Abdullateef,2014).

The issues of knowledge management lifecycle offer firms with active potentials for positively driving knowledge quality and for strengthening the value and applicability of knowledge to deliver quality and sustainability outcomes, companies need to build both human and material capacities for the creation, application and management of ever increasing knowledge. This project anticipates establishing the importance and key issues of promoting decision making through knowledge management. It presents a new conceptual model for managing knowledge by creating awareness and directing further research. Allencompassing knowledge management approach is adopted in this research to consider the ability to deliver the proper information to the right person at the right time in the context of decision making.

Knowledge management is the generation, distribution, access and use of knowledge coded into artifacts or information. The general purpose of Knowledge Management is to make knowledge usable for more than one individual, e.g. for an organization as a whole; that is, to share it. New knowledge-based views on corporations suggest that it is knowledge that holds companies together (Brown and Duguid, 1998). KM has existed and has been used for a long time, although it was neither called by this name nor necessarily recognized as what it is until some years ago (Davenport and Prusak, 1998). The way of making knowledge available for others has changed with time. It once started with family members, where knowledge was passed on from father to son by a long process of learning. With the help of teamwork, people were supposed to work.

Today however, it is very relevant at this point to note that knowledge comes in different forms or types. That is Nonaka \& Takeuchi (1995) stresses that there is a difference between tacit and explicit knowledge. Tacit knowledge is knowledge in the human mind and it is hard to externalize or change. Explicit knowledge is formalized knowledge, i.e. knowledge recorded as video, in a paper, etc. and usually covers part of the original tacit knowledge but is not a full picture of it. Implicit knowledge can be transferred throughout any direct face-toface communication between people or by transmitting it into explicit knowledge and sharing the article. The transformation back to tacit knowledge carries on during the reading and understanding of explicit knowledge.

On the other hand, in today's complex and turbulent environment, knowledge management has become increasingly important in decision making. Unlike in the past where organizations employed consultants or experts to aid with the decision making process, these 
actors have today been replaced by knowledge managers and decision making is increasingly being supported by decision support systems with built in knowledge base (Gamble, 2001).

In this view, this project examines the relationship between knowledge management and decision making. There is no universally accepted definition of the term 'Knowledge management'. However, in this context, it will be used in reference to the strategies and practices used by an organization to capture, store and distribute knowledge that is either embodied in individuals or embedded in the process and practices of the organization (Holsapple, 1995).

As noted by Joshi (2001), knowledge management has important implications on decision making in an organization. Effective KM should support the process of decision making and strategic planning. For example, knowledge management plays a major role in the planning phase of a project. Based on the current information, forecasters guide decision makers in making complex decisions in the business world characterized by increased risks and uncertainty. The entire decision making endeavour is made based on the outcome of forecasting, a knowledge intensive activity (Mohammed \& Jalal, 2011). Knowledge management is thus important in tactical decision making.

Knowledge management in organizations is supported by information technology. That is, Knowledge Management Systems rely on routines programmed in the logic of computational machinery (Malhotra, 2004). The expertise and experiences of employees are stored in computerized databases. Both the tacit and explicit knowledge are stored in computerized databases and software programs for re-use in future (Malhotra, 2004). In fact, most of the knowledge management experts acknowledge that technology contributes around $15 \%$ of the solution. However, technology in itself is not sufficient. Of great importance are the people with knowledge. People are the main determinant of the success or failure of knowledge management.

A perfect case where knowledge management can guide decision making is in the PC market. Given the competitive environment which has resulted in diminishing margins in the PC markets, Dell may need to shift focus to hosting services (Malhotra, 2004). To do so more effectively, Dell would first have to harvest knowledge through experimentation, adaptation and innovation (Malhotra, 2004). Then it would need to redefine both the business and customer value propositions.

Another area where knowledge management has proven to be useful in decision making is the banking sector. Due to increase in competition and the growing integration of financial institutions, most banks are increasingly targeting at improving on customer satisfaction in order to continue to thrive. As such, the process of knowledge creation, storage and distribution has become essential such that banks have assigned specialized personnel to manage these critical processes (Mohsen et al., 2011).

Knowledge management in banks is particularly evident in the fields of risk management, performance management, customer relationship management and marketing management. Banks have invested heavily in knowledge management systems such as Decision Support Systems, Data Mining and Data warehouses. Through such systems, banks have been able to improve and attain more efficient results in decision making. 
According to a survey by Reuters, it was found that $90 \%$ of the companies that deployed a KM solution had more efficient results in decision making (Malhotra, 2001). The survey also revealed that $81 \%$ of the companies that deployed a KM solution experienced an increase in their productivity (Malhotra, 2001). A similar study by Lui \& Young (2007) in the manufacturing sector showed that global manufacturing businesses utilized knowledge management systems such as Enterprise Resource Planning (ERP), Product Life Cycle Management (PLM) and Customer Relations Management to enhance their manufacturing decisions.

Given the vital role that knowledge management plays in decision making, it is not surprising to find many organizations transforming knowledge from being an abstract concept to a tangible and manageable one (Oduoza, 2010). But, whilst there is a general agreement that knowledge management enhances the decision making process and leads to worthwhile decisions, there are certain instances where such systems can fail. The connection between knowledge management lifecycle and organizational decision making in the paint manufacturing companies in Rivers State was limited by previous studies. Having identified this gap, the researcher developed the interest in investigate the relationship between knowledge management and organizational decision making in the context of pain manufacturing companies in Rivers State.

\section{Statement of the Problem}

The problem that called our interest to carry out this study is poor decision making system within the organization which has led to poor implementation of knowledge management lifecycle. Where knowledge management and information systems are seen as an end in themselves, failure is guaranteed. 'Knowledge' and 'information' have different meanings. Knowledge resides in the user and happens only through the processing, analyzing and filtering of data via humans. On the other hand, information refers to refined data that can be re-used. The two are not the same yet many organizations fail to understand the difference and become frustrated when significant investments in technology fail to deliver the expected results (Paprika, 2001).

In order to harvest employee knowledge and to turn it into corporate knowledge that can be widely shared, strategic thinking and planning must come into play. Without a strategic plan or a guiding strategy for increasing margins, knowledge management and information systems are bound to fail. For example, if the technology department is only department mandated with a knowledge management initiative, then such systems are unlikely to deliver the expected outcomes.

To ensure the success of knowledge management lifecycle, it is important to foster an environment that allows for knowledge sharing. Yet most organizations are still defined by hierarchical structures that do not support interdepartmental collaboration (Paprika, 2001). Creating an organizational culture that supports sharing of knowledge is important to avoid such systems from failing.

Also, too much focus on IT-based knowledge management may impair a company's capacity for knowledge creation (Bayo \& Kayii, 2020; Malhotra, 2000). Solutions often tend to specify the 'minutiae of machinery', ignoring the human psychology of how people in the organization acquire, share and create knowledge (Malhotra, 2000). Such constrained and 
restricted perspective of knowledge management can be detrimental on a company's learning and adaptive capabilities (Malhotra, 2000).

In fact, it becomes more problematic in a dynamic environment that requires multiple interpretations and ongoing evaluation (Malhotra, 2000). In order to address this weakness inherent in IT-based knowledge management, it is equally important to focus on the synergy of innovation and human creativity. Nonetheless, the process of decision making is a knowledge intensive activity. Explicit knowledge that is obtained from repositories and the tacit knowledge that is obtained through a one on one interaction between a manager and an employee can be used to support decision making.

But still, managing knowledge is no easy task. As suggested by acquiring knowledge is not the real problem that organizations face, rather the main challenge is the lack of skills to manage such knowledge in order to ensure effective decisions. It is a major challenge to capture knowledge such as data, information and experiences from individuals that possess them and to use such ingredients and transform them into knowledge that would enhance decision making (Mohsen et al., 2011).

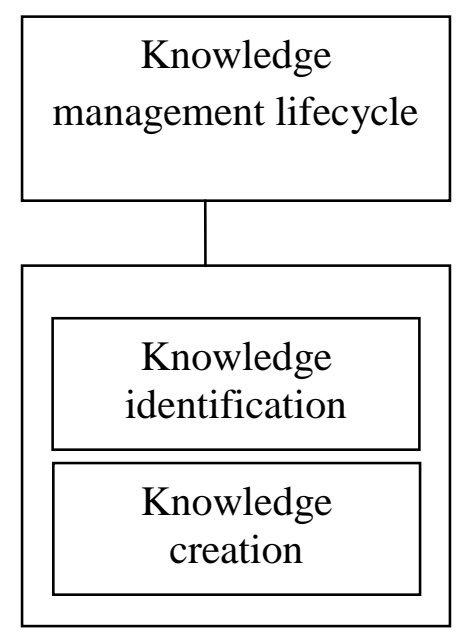

Purpose of the Study

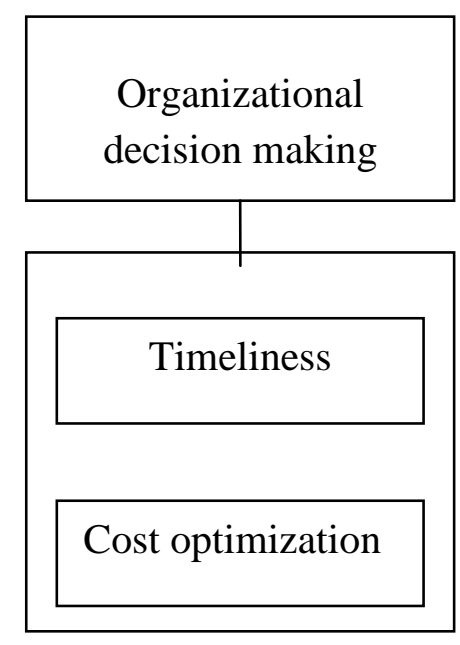

Generally, the study examined the relationship between knowledge management lifecycle and organisational decision making of paint manufacturing companies in Rivers State. Objectively, the study sought to;

i. Ascertain the association of knowledge identification and organizational decisions making in paint manufacturing companies in Rivers State.

ii. Examine the association of knowledge creation and organizational decision making in paint manufacturing companies in Rivers State. 


\section{Research Questions}

i. To what extent does knowledge identification influence organizational decisions making in paint manufacturing companies in Rivers State?

ii. To what extent does knowledge creation influence organizational decision making in paint manufacturing companies in Rivers State?

\section{Hypotheses}

Ho: There is no significant relationship between knowledge identification and timeliness in paint manufacturing companies in Rivers State, Nigeria.

Ho2: There is no significant relationship between knowledge identification and cost optimization in paint manufacturing companies in River State, Nigeria.

Ho3: There is no significant relationship between knowledge creation and timeliness in paint manufacturing companies in Rivers State, Nigeria.

Ho4: There is no significant relationship between knowledge creation and cost optimization in paint manufacturing companies in Rivers State, Nigeria

\section{Review of Related Literature}

\section{Organizational Decision Making}

The literature on organizational decision-making processes is extensive, with origins predating Simon's (1997) Administrative Behaviour: a study of decision-making processes in administrative organizations which was originally published in 1947. Both Nutt (1976) and Smallman and Moore (2010) identify six paradigms in organizational decision-making theory, which align more or less. The first paradigm is the classical concept of prescriptive, analytical or bureaucratic decision-making (Edwards, 1954; Fayol, 1949; von Neumann \& Morgenstern, 1944; Weber, 1947), which claims that people collect and analyse information, eventually selecting an optimal solution from a range of alternatives. They do so by evaluating the advantages and disadvantages of each possible outcome and then choosing the one most appropriate to achieve their desired objective. However, in its original formulation classical decision theory assumes 'pure' rationality. Prospect theory (Kahneman) tackles this assumption in accommodating the notions of risk or uncertainty in decisions. This approach is also an example of what Nutt (1976), refers to as normative decision theory.

While this paradigm offers an apparent improvement over bureaucratic theory, it still fails to address the 'mediating processes that lead to a decision' (recognised in developing behavioural decision theory - the second paradigm - was that decision-making is bounded by limits on time, cognition and information. Bounded rationality (Cyert \& March, 1992; March $\&$ Simon, 1958) takes the realistic view that individuals make decisions that are 'good enough' rather than optimal, based on the limits of the information and knowledge they have. A variant of behavioural decision theory, is the third paradigm of adaptive decision making theory (Payne, Bettman, \& Johnson, 1993) that allows for natural dynamics in solving problems, finding that individuals use a variety of problem solving strategies, depending 
upon personal traits or characteristics, and problem and social contexts (i.e., bounds on their rationality).

In any business, there are uncertainties with respect to the behaviour of the market, the deliveries from the suppliers, the behaviour and expectations of customers, the attitudes of shareholders, the behaviour of competitor companies, future actions of government agencies and so on. As a result, much of modern decision-making theory has been concerned with the problems of decision-making under risks and uncertainty. The solutions involved have been largely procedures for finding certainty equivalents or introducing rules for living with the uncertainties. Studies indicate that firms achieve a manageable decision situation by avoiding planning that depends on predictions of uncertain future and rather emphasizing planning that is based on feedback decision procedures. Companies also make some predictions about the behaviour of their environment, especially the environment that is represented by competitors, suppliers, customers within a specific timeframe.

\section{Timeliness}

Timeliness reflects the ability of the organization to produce a response within an allotted time by determining the task requirements. Delays in completing a task are due both to the time required for processing information and making decisions and to the time required to effect communications among decision makers. Organizations are formed when the task to be performed exceeds the capabilities of a single decision maker. Even when a single person can complete the task, he may not be able to produce a satisfactory response within the time limits imposed by the task. The organization designer is faced with the problem of designing an organization that will meet these design specifications and, in addition, assign subtasks or functions to members of the organization so that no one is overloaded. The design has to be robust to accommodate the different decision making styles of different actual decision makers that may instantiate the organization at different times. Consider, for example, the design of an air traffic control center for a busy airport area. The task cannot be done by a single controller; several controller stations may be required. The designer has to take into account the uncertainty that is inherent in the task and the need for accurate and timely responses by the controllers. But he also has to consider that different controllers will be on duty at any instant of time. While they are all well trained for their tasks, their actual information processing and decision making styles will differ.

At some point, every manager will face a big career making or career breaking decision. Depending on whether or not they make the right choice, these decisions can be wildly successful, or they can have a detrimental impact on a manager's ability to meet the strategic objectives delegated to them. It's no surprise that managers often get bogged down by the decision-making process. As a manager, it's important to trust your gut and not miss the window of opportunity to make decisions that are impactful and effective cost optimization.

\section{Cost Optimization}

Cost concept is the sum of the marginal costs over the range of each output differential between the alternatives under review.' In practice, this is often approximated by the summation of average variable cost (assumed to be constant over the affected output range), with differential fixed costs recognized when significant. Also, cost concept was define as the change in total cost resulting from a one-unit change in output when the firm has ample time 
to meet the changing in out- put by changing the scale of the plant. This definition may be amplified by providing that the firm may change not only the scale of its plant but its methods as well. It also could be objected that the one-unit increment is too small to have any operational meaning, particularly in view of the indivisibilities in many of the productive inputs.

Cost Optimization is the continuous process of obtaining the best pricing/cost with no impact or reduction in scope of service delivery and ensuring the customer satisfaction scores are maintained. Decision-makers often resort to cost-cutting measures in response to business pressures to reduce IT spend. However, by focusing on short-term cost-cutting within organizational siloes and without the context of the business strategy and technology roadmap, these initiatives often result in higher IT costs in the long term and, in some cases, are abandoned altogether.

Manufacturing organizations face a strategic increasing revenue and decreasing costs to enhance profitability. In this situation, cost optimization is often thought to be a purely cost reduction exercise. However, discussed the cost optimization aims at reducing the costs 'built-in' the product; this will ultimately help in increasing the profit margin of the product by lowering the price, and expand the footprint of the product in virgin markets as also in existing markets. Cost optimization based on process estimation criteria. However, obtaining the optimized results could be a pest time consuming, when there are a large number of processes to be evaluated. Cost optimization techniques to specific methods for overhead cost, from exceptional approaches for estimation at the conceptual design stage to general costing rules designed for use at a later stage in the design cycle. Also, from classical costing methods are to highly novel cost estimation techniques.

Cost optimization plays an important role in a firm's to growth. It requires focus on full cost structure, culture of optimizing the costs, systems for continuous cost evaluation, and access to different cost optimization techniques. For manufacturing organizations, cost optimization requires a holistic view on the cost across the complete product realization value chain. Through effective cost optimization, firms could create differentiated products; improve their potential for innovation. During the past decades, global competitiveness has been increased drastically. Many manufacturing companies are trying to implement lean manufacturing and its tools to achieve their goals, vision, and mission. In order to be more competitive many companies, adopt new technologies like lean manufacturing (Shah \& Ward, Lean manufacturing: context, practice bundles, and performance, 2003) The cost involved in the manufacturing sectors or production industries plays a major role and have a huge impact on the problems like production, consumption, price, redundancy, intensification, and economic growth (Zaharia \& Bordeianu, 2018).

\section{Knowledge Management Lifecycle}

Davenport and Prusak (1998) view knowledge as an evolving mix of framed experience, values, contextual information, and expert insight that provides a framework for evaluating and incorporating new experiences and information. They found that in organizations, knowledge often becomes embedded in documents or repositories and in organizational routines, processes, practices, and norms. They also say that in order for knowledge to have value, it must include the human additions of context, experience, and interpretation. Nonaka (1994) expands this view by stating that knowledge is about meaning in the sense that it is 
context-specific. This implies that users of knowledge must understand and have experience with the context, or surrounding conditions and influences, in which the knowledge is generated and used in order for it to have meaning to them. This also implies that in order for a knowledge repository to be useful, it also must store the context in which the knowledge was generated. That knowledge is context-specific and argues against the idea that knowledge can be applied universally; however, it does not argue against the concept of organizational knowledge. This considers organizational knowledge to be an integral component of what organizational members remember and use, meaning that knowledge is actionable.

\section{Knowledge Identification and Organizational Decision Making}

Knowledge is the primary driver of performance of individual, consequently the organization as a whole. Knowledge affects performance by making it possible for people to perform good and effective actions. Application of knowledge provides opportunities for higher performance. Although the term used widely is knowledge management, in fact the real value stems from creating and sharing knowledge not from just barely managing it. Over the past 15-20 years many heavy investments were made into "knowledge management systems" but the benefits have been limited, because they were made just for the sake of managing the knowledge rather than creating and sharing (Bryan and Joyce, 2005).

This is the heart of the problem. The usage and creation of knowledge from the stored knowledge is the most crucial point of knowledge management, i.e. the ability to work with the knowledge to produce results. The knowledge had become important "manufacturing" factor, so the organization should put it in the "production" process. This means to apply the gathered knowledge. However, there are still some remnants from the Industrial Age. One of them is the rigid organizational structure, which is still causing nightmares for knowledge workers. The era of globalization created large multinational corporations with thousands of employees. An employee many times can spend the whole day just searching for the person who has the knowledge. This can be observed especially in cross-divisional, cross departmental not to mention cross country communication. Brief example is that the volume of global corporate e-mail has increased almost ten times from 1998 (1.8 billion a day) to 2004 (17 billion a day).

\section{Knowledge Creation and Organizational Decision Making}

Knowledge management deals equally with the acquisition, handling and use of explicit knowledge as well as the management of tacit knowledge in terms of improving people's capacity to communicate and collaborate with one another (Al-Hawamdeh, 2002). Knowledge management is a capability pertaining to knowledge creation, knowledge organization, storage and retrieval, knowledge transfer, and knowledge applications which enhances a firm's ability to gain and sustain a competitive advantage (Carlsson, 2008). Knowledge acquisition means the development or creation of skills, insights and relationships. Nonaka and Takeuchi (1995) proposed knowledge creation process which is made up of sharing tacit knowledge, creating concepts, justifying concepts, building archetype and cross leveling knowledge. Knowledge generation includes all activities which bring to light knowledge which is new, whether to the individual, to the group, or to the world. Knowledge codification is the capture and representation of knowledge so that it can be re-used either by an individual or by an organization. Knowledge transfer involves the movement of knowledge from one location to another and its subsequent absorption. Creation 
and manifestation is related to how it is created and manifested in people's minds as well as procedures, culture and even technology.

\section{METHODOLOGY}

In line the objective of the study, the design adopted for this study is the cross-sectional survey design which allows for the summarization and quantification of data obtained from a variety of targets or units within a specified time.

The population of this study comprises all Managerial staff in the paint subsector of the economy. Information obtained from the business (Yellow Page, 2013/2014 edition) unit of Rivers state Ministry of Commerce and Industry, Port-Harcourt was used as the population for the study shows that a total number of fifty-one (51) registered manufacturing firms in Rivers State. The purposive sampling method was used to select the number of respondents for a study as it aims to provide a sample that reflects the population of the study. Based on predetermined parameters. The purposive sampling technique was adopted to select 90 respondents. This study used a well-structured and a close-ended questionnaire titled knowledge management lifecycle and organizational decision making of selected paints manufacturing companies in Rivers State, Nigeria, as the tool for survey research. The questionnaire consists of two main sections, A and B. Section A contains items on socio demographic characteristics of the respondent which include: gender, age and year of service. Section B consisted of the questions in line with the research objectives. The instrument was designed in a 5- likert rating scale ranging from "Very High Extent" (VHE), through "High Extent" (HE), "Moderate Extent" (ME), "Low Extent" (LE), to "Very Low Extent" (VLE). The study sought responses from key informants by identifying the managers and supervisors selected from each of the thirty (30) selected registered paint manufacturing firms in Rivers State as key informant on the basis of their position, as representative of the primary users of the firms' knowledge management lifecycle activities information and have eagle eyes view of their efficiency and effectiveness. According to Bayo and Kayii (2020), to increase the quality of key informant responses and reduce common method variance, the researcher guaranteed participants anonymity and confidentiality in the analysis and reporting of results are essential to remove bias. The instrument used was subjected to face/content validity; this was done to ascertain the validity of the questionnaires to be administered. A complete copy of the questionnaire was given to the supervisor for vetting and correction. The researcher collected the questionnaire from the supervisor after vetting and correction effected before administration of the instrument. However, the researchers verified the reliability outcomes through confirmatory test of internal consistency on the instrument with our sample using Cronbach alpha. This calculates the average of all possible Split-half Reliability Coefficient and the threshold level, 0.73 which is generally accepted by the rule of thumb (Nunnally, 1978) was considered adequate. The study used a quantitative method of data analysis. This method is made up of both the descriptive and inferential statistical tools which could be used to analyze the data. The information collected from the questionnaire was summarized in their groups and percentage was used to analyze the data, also inferential statistical tool of regression analysis was used to test the level of significance among variables and finally, the analysis was aided with SPSS version 21.0. 


\section{RESULTS}

\section{Relationship between Knowledge Identification and Organizational Decision Making}

Table 1 below shows the result of correlation matrix obtained for knowledge identification and organizational decision making. Also displayed in the table is the statistical test of significance ( $\mathrm{p}$ - value), which makes us able to answer our research question and generalize our findings to the study population.

Table 1: Correlation Matrix for knowledge identification and organizational decision making

\begin{tabular}{|c|c|c|c|c|c|}
\hline & & & $\begin{array}{c}\text { Knowledge } \\
\text { identification }\end{array}$ & Timeliness & Cost optimization \\
\hline \multirow{10}{*}{$\begin{array}{l}\text { Spearman's } \\
\text { rho }\end{array}$} & \multirow{3}{*}{$\begin{array}{l}\text { Knowledge } \\
\text { identification }\end{array}$} & $\begin{array}{l}\text { Correlation } \\
\text { Coefficient }\end{array}$ & 1.000 & $.926^{* *}$ & $.969^{* *}$ \\
\hline & & Sig. (2-tailed) & & .000 & .000 \\
\hline & & $\mathrm{N}$ & 121 & 121 & 121 \\
\hline & \multirow{3}{*}{ Timeliness } & $\begin{array}{l}\text { Correlation } \\
\text { Coefficient }\end{array}$ & $.926^{* *}$ & 1.000 & $.968^{* *}$ \\
\hline & & Sig. (2-tailed) & .000 & & .000 \\
\hline & & $\mathrm{N}$ & 121 & 121 & 121 \\
\hline & \multirow{4}{*}{$\begin{array}{l}\text { Cost } \\
\text { optimization }\end{array}$} & $\begin{array}{l}\text { Correlation } \\
\text { Coefficient }\end{array}$ & $.969^{* *}$ & $.968^{* *}$ & 1.000 \\
\hline & & Sig. (2-tailed) & .000 & .000 & \\
\hline & & $\mathrm{N}$ & 121 & 121 & 121 \\
\hline & & $\mathrm{N}$ & 121 & 121 & 121 \\
\hline
\end{tabular}

**. Correlation is significant at the 0.01 level (2-tailed).

Table 1 illustrates the test for the three previously postulated bivariate hypothetical statements. The results show that for hypothesis one; there is no significant relationship between knowledge identification and timeliness $(\mathrm{r}=0.926, \mathrm{p}=0.000<0.01)$, hypothesis two; There is no significant relationship between knowledge identification and cost optimization $(\mathrm{r}=0.969, \mathrm{p}=0.000<0.01)$. Therefore based on the results illustrated, all previous bivariate null hypothetical statements are hereby rejected as the study finds that:

- There is a significant relationship between knowledge identification and timeliness in paint manufacturing companies in Port Harcourt, Rivers State.

- There is a significant relationship between knowledge identification and cost optimization in paint manufacturing companies in Port Harcourt, Rivers State.

\section{Relationship between Knowledge Creation and Organizational Decision Making}

Table 2 below shows the result of correlation matrix obtained for knowledge creation and organizational decision making. Also displayed in the table is the statistical test of significance ( $\mathrm{p}$ - value), which makes us able to answer our research question and generalize our findings to the study population. 
Table 2: Correlation Matrix for Knowledge Creation and Organizational Decision Making

\begin{tabular}{|c|c|c|c|c|c|}
\hline & & & $\begin{array}{l}\text { Knowledge } \\
\text { Creation }\end{array}$ & timeliness & $\begin{array}{c}\text { Cost } \\
\text { optimization }\end{array}$ \\
\hline \multirow{10}{*}{$\begin{array}{l}\text { Spearman's } \\
\text { rho }\end{array}$} & \multirow{3}{*}{$\begin{array}{l}\text { Knowledge } \\
\text { Creation }\end{array}$} & $\begin{array}{l}\text { Correlation } \\
\text { Coefficient }\end{array}$ & 1.000 & $.949^{* *}$ & $.875^{* *}$ \\
\hline & & $\begin{array}{l}\text { Sig. }(2- \\
\text { tailed })\end{array}$ & . & .000 & .000 \\
\hline & & $\mathrm{N}$ & 121 & 121 & 121 \\
\hline & \multirow{3}{*}{ Timeliness } & $\begin{array}{l}\text { Correlation } \\
\text { Coefficient }\end{array}$ & $.949^{* *}$ & 1.000 & $.968^{* *}$ \\
\hline & & $\begin{array}{l}\text { Sig. (2- } \\
\text { tailed) }\end{array}$ & .000 & • & .000 \\
\hline & & $\mathrm{N}$ & 121 & 121 & 121 \\
\hline & \multirow{4}{*}{$\begin{array}{l}\text { Cost } \\
\text { optimization }\end{array}$} & $\begin{array}{l}\text { Correlation } \\
\text { Coefficient }\end{array}$ & $.875^{* *}$ & $.968^{* *}$ & 1.000 \\
\hline & & $\begin{array}{l}\text { Sig. (2- } \\
\text { tailed) }\end{array}$ & .000 & .000 & • \\
\hline & & $\mathrm{N}$ & 121 & 121 & 121 \\
\hline & & $\mathrm{N}$ & 121 & 121 & 121 \\
\hline
\end{tabular}

**. Correlation is significant at the 0.01 level (2-tailed).

Table 2 illustrates the test for the three previously postulated bivariate hypothetical statements. The results show that for hypothesis three; there is no significant relationship between knowledge creation and timelines $(\mathrm{r}=0.949, \mathrm{p}=0.000<0.01)$, hypothesis four; There is no significant relationship between knowledge creation and cost optimization $(\mathrm{r}=$ $0.875, \mathrm{p}=0.000<0.01)$.

Therefore based on the results illustrated, all previous bivariate null hypothetical statements are hereby rejected as the study finds that:

- There is a significant relationship between knowledge creation and timeliness in paint manufacturing companies in Port Harcourt, Rivers State.

- There is a significant relationship between knowledge creation and cost optimization in paint manufacturing companies in Port Harcourt, Rivers State.

\section{Discussion of Findings}

Paint manufacturing companies operate in a dynamic and turbulent environment which has made them expand on their products and borders with the motive of searching for market, resources and achievement of efficiency. From the study, the paint manufacturing companies have engaged in various strategic approaches aimed at increasing their competitive edge in the industry. In this regard, the companies have reviewed product/services prices to match or be lower and introduce a new product to the market. Knowledge utilization according to Estabrooks (1999) is the use of knowledge, regardless of the kind of knowledge. The utilization of knowledge in whatever form by companies in Nigerian has been studied by Ehikamenor (2003); Aduwa-Ogiegbean and Stella (2006); Adogbeji and Toyo (2006). 
Shokeen and Kaushik (2002) noted that special scientists of Harrana University in India most frequently used current journals, textbooks and reference books. As librarians make use of the knowledge shared among their professional colleagues, there is every tendency for better quality and efficient research output (research productivity). Knowledge storage involves both the soft or hard style recording and retention of both individual and organizational knowledge in a way so as to be easily retrieved. Knowledge storage utilizes technical infrastructure such as modern informational hardware and software and human processes to identify the knowledge in an organization, then to code and index the knowledge for later retrieval (Nonaka and Takeuchi, 1995; Armstrong, 2000:2006). This approach encourages people to document approach. A repository as argued by Armstrong, (2006) allows many people to search for, and retrieve codified knowledge without having to contact the person who originally developed it.

\section{CONCLUSION}

The paint manufacturing companies operate across various regions where the operating environments and the socio- economic characteristic of the customers are different, calling on these companies to apply various knowledge management life cycle methods to survive in the industry is important. Referring back to our finding where knowledge identification, sharing, transfer and acquisition affect the organizational timeliness and cost optimization as an indication of why firms should be conscious of their various strategies to achieve their ultimate goal.

\section{RECOMMENDATIONS}

The following recommendations were made:

i. The government should put in place appropriate policies which support the manufacturing sector as a way of increasing their contribution to the economy. It is clearly demonstrated in the result that the various dimension used in this study are important partial determinant of the measures of the level of entrepreneurial orientation.

ii. The relevant authorities should also work towards setting policies and standards governing the performance of the sector, this would be in an attempt to protect them from the adverse effects of knowledge management environment brought about by globalization and rise in technological advancement. 


\section{REFERENCES}

Bayo, P.L \& Kayii, N.E (2020). Knowledge-based entrepreneurship: an agent for economic development. International Journal of Advanced Academic Research (Social and Management Sciences), 6(8), 32-42.

Brown, J. S. \& Duguid, P. (1998). Organizational learning and communities-of-practice. Organization Science, 2, 40-57.

Choi, J. H., Lee, T. I., Han, I., Baik, H. K., Song, K. M., Lim, Y. S., \& Lee, E. S. (2006). Investigation of the transition between glow and streamer discharges in atmospheric air. Plasma Sources Science and Technology, 15(3), 416.

Cyert, R. M., \& March, J. G. (1963). A behavioral theory of the firm: Prentice-Hall Inc., New Jersey, USA.

Davenport, T.\& Prusak, L. (1998). Working knowledge: How organizations manage what they know. Cambridge, MA: Harvard Business School Press.

Davenport, T. H., \& Prusak, L. (1998). Working knowledge. Boston, MA: Harvard Business School Press.

De Long, D., (1997).Building the knowledge-based organization: How culture drives knowledge behaviors, Center for Business Innovation, Ernst \& Young LLP.

Decrop, A. (2006). Vacation decision making: CABI.

Gamble, P.R., (2001). Knowledge management: a state of the art guide. Kogan Publishers.

Ganzaroli, A., De Noni, I., Orsi, L., \& Belussi, F. (2016). The combined effect of technological relatedness and knowledge utilization on explorative and exploitative invention performance post-M\&A. European Journal of Innovation Management, 19(2), 167-188.

Githinji, A. (2014). Effects of training on employee performance: A case study of United Nations support office for the African Union mission in Somalia. (Masters Thesis, Chandaria School of Business, United States International University). Retrieved from http://erepo.usiu.ac.ke/bitstream/handle/11732/71/ANGELA.pdf?sequence=1

Gold, A. H., Malhotra, A., \& Segars, A. H. (2001). Knowledge management: An organizational capabilities perspective. Journal of Management Information Systems, 18(1), 184-214.

Golsorkhi, D., Rouleau, L., Seidl, D., \& Vaara, E. (2010). Strategy as Practice: Cambridge University Press.

Gonzalez, R. V. D., Martins, M. F., \& Toledo, J. C. (2014). Mapping the organizational factors that support knowledge management in the Brazilian automotive industry. Journal of Knowledge Management, 18(1), 611-630. 
Gonzalvez, M. A. A., Toledo, O. A. C., \& Rodriguez, A. R. I. (2014). The management and construction of knowledge as an innovation strategy for collaborative learning through the use and creation of learning communities and networks. International Journal of Knowledge Management, 10(4), 38-49.

Gore, J., Banks, A., Millward, L., \& Kyriakidou, O. (2006). Naturalistic decisionmaking and organisations: reviewing pragmatic science. Organization Studies, 27(7), 925-942.

Grant, R. M. (1996). Toward a knowledge-based theory of the firm. Strategic Management Journal, 17(1), 109-122.

Greenberg, J., \& Baron, R. A. (2003). Behavior in organizations: Understanding and managing the human side of work. Englewood Cliffs, NJ: Prentice

Holmqvist, M. (2004). Experiential learning processes of exploration and exploitation within and between organizations: An empirical study of product development. Organization Science, 15(1), 70-81.

Holsapple, C. W., \& Joshi, K. (2004). A formal knowledge management ontology: Conduct, activities, resources, and influences. Journal of the American Society for Information Science and Technology, 55(7), 593-612.

Holsapple, C.W., (1995). Knowledge management in decision making and decision support. TheInternational Journal of Knowledge Transfer and Utilization, 8(1), 5-22

Huysman, M., \& Wulf, V. (2006). IT to support knowledge sharing in communities, towards a social capital analysis. Journal of Information Technology, 21(1), 40-51.

Hwang, E. H., Sinh, P. V., \& Argote, L. (2015). Knowledge sharing in online communities: learning to cross geographic and hierarchical boundaries. Organization Science, 26(6), 1593-1611.

Kahneman, D., \& Tversky, A. (1979). Prospect Theory: An analysis of decision under risk. Econometrica, 47(2), 263-291.

Kakabadse, N. K., Kakabadse, A., \& Kouzmin, A. (2003). Reviewing the Knowledge management: Towards a taxonomy. Journal of Knowledge Management, 7(4), 75-91.

Karlin, S., \& Taylor, H. (1998). An introduction to stochastic modeling. Orlando, Fla: Harcourt.

Klayman, Ben (2012), GM focusing on profits, not U.S. market share: CEO, Reuters (January9), http://www.reuters.com/article/us-gm-usshareidUSTRE8081MU20120110.

Klein, G. A. (1998). Sources of power: How people make decisions: MIT Press.

Kogut, B., \& Zander, U. (1992). Knowledge of the firm, combinative capabilities and the replication of technology. Organization Studies, 3(1), 383-397. 
Kolb, D. (1984). Experimental learning. Englewood Cliffs, NJ: Prentice-Hall.

Kollat, D T, Blackwell, R. D.\& Robfson, J. (1972). Strategic Marketing. HoltRinehart \& Winston, New .York.

Langley, A., Van de Ven, A. H., Smallman, C., \& Tsoukas, H. (2013). Introduction to the special issue. Academy of Management (in press).

Lave, J. (1998). Cognition in practice: Mind, mathematics and culture in everyday life. Cambridge: Cambridge University Press.

Lawler, E. E. (2003). Reward practices and performance management 52 system effectiveness. Center for effective organizations.

Lee, C., \& Yang, J. (2000). Knowledge value chain. Journal of Management Development, 19(9), 783-794.

Lee, J. H., \& Kim, Y. G. (2001). A stage model of organizational knowledge management: a latent content analysis. Expert Systems with Applications, 20(3), 299-311.

Lefebvre, V. M., Sorenson, D., Henchion, M., \& Gellynck, X. (2016). Social capital and knowledge sharing performance of learning networks. International Journal of Information Management, 36(4), 570-579.

Lehaney B., Jack G., Clarke S., \& Coakes E. (2003). Beyond knowledge management. Hershey, PA: Idea Group Publishing.

Lehaney, B., (2004). Beyond knowledge management. Idea Group Inc.

Levine, S. S., \& Prietula, M. (2012). How knowledge transfer impacts performance: A mutilevel model of benefits and liabilities. Organization Science, 23(6), 1748-1766.

Levy, M. (2011). Knowledge retention: Minimizing organizational business loss. Journal of Knowledge Management, 15(4), 582-600.

Liao, C., Chuang, S. H., \& To, P. L. (2011). How knowledge management mediates relationship between environment and organizational structure. Journal of Business Research, 64(7), 728-736.

Liao, S., Wu, C., Hu, D., \& Tsui, K. (2010). Relationships between knowledge acquisition, absorptive capacity and innovation capability: An empirical study on Taiwan's financial and manufacturing industries. Journal of Information Science, 36(1), 19-35.

Liew, A., (2007). Understanding data, information, knowledge and their interrelationships. Journal of knowledge Management Practice, 8(2).

Lin, H. F. (2007). A stage model of knowledge management: an empirical investigation of process and effectiveness. Journal of Information Science, 33(6), 643-659. 
Lipshitz, R., Klein, G., \& Carroll, J. S. (2006). Introduction to the special issue. Naturalistic decision making and organisational decision-making: Exploring the intersections. Organization Studies, 27(7), 917-924.

Lopez, V. W. B., \& Esteves, J. (2012). Acquiring external knowledge to avoid wheel reinvention. Journal of Knowledge Management, 17(1), 87-105.

Madsen, T. L., Mosakowski, E., \& Zaheer, S. (2003). Knowledge retention and personnel mobility: the nondisruptive effects of inflows of experience. Organization Science, 14(2), 173-191.

Magnier-Watanable, R., \& Senoo, D. (2008). Organizational characteristics as prescriptive factors of knowledge iniciatives. Journal of Knowledge Management, 12(1), 21-36.

Malhotra, Y., (2000). From information management to knowledge management: Beyond the 'hi-tech hidebound' systems'. In: K. Srikantaiah \& M.E.D. Koenig (eds), knowledge management for the information professional. Medford, N.J., Information Today Inc., 37-61.

Malhotra, Y., (2001). Expert Systems for Knowledge Management: Crossing the chasm between information processing and sense making. Expert Systems With Applications, 20(1), 7-16.

Malhotra, Y., (2004). Why Knowledge Management Systems Fail? Enablers and Constraints of Knowledge Management in Human Enterprises'. In: Michael E.D. Koenig \& T. Kanti Srikantaiah (Eds.), Knowledge Management Lessons Learned: What works and what doesn't, information today Inc. American Society for Information Science and Technology Monograph Series, 87-112.

March, J. G., \& Simon, H. A. (1958). Organisations. New York: Wiley.

March, J. G., \& Simon, H. A. (1993). Organisations. (second edition ed.). Cambridge, Massachusetts: Blackwell Publishers.

Martín-de-Castro, G. (2015). Knowledge management and innovation in knowledge-based and high-tech industrial markets: the role of openness and absorptive capacity. Industrial Marketing Management, 47(1), 143-146.

Martins, E. C., \& Meyer, H. W. J. (2012). Organizational and behavioral factors that influence knowledge retention. Journal of Knowledge Management, 16(1), 77-96.

Maslow, A. (1954). Motivation and Personality. New York: New York Harper\& Row.

McAfee, R. Preston, \& John McMillan (1995). Organizational Diseconomies of Scale, Journal of Economics \& Management Strategy, 4 (3), 399-426.

Merat, A., \& Bo, D. (2013). Strategic analysis of Knowledge firms: The links between knowledge management and leardership. Journal of Knowledge Management, 17(1), 3-15. 
Miguel, P. A. C. (2007). Estudo de caso na engenharia de produção: Estrutura e recomendações para sua condução. Produção, 17(1), 216-229.

Miller, D. (1996). A preliminary typology of organizational learning: Synthesizing the literature. Journal of Management, 22(3), 485-505.

Mohammed, W. \& Jalal, A., (2011). The influence of knowledge management system (KMS) on enhancing decision making process (DMP). International Journal of Business and Management, 6(8).

Molina, V. B., Amado, J. B., \& Arostegui, M. N. P. (2010). Managerial perceptions of the competitive environment and dynamic capabilities generation. Industrial Management \& Data Systems, 110(9), 1355-1384.

Morrison, J. (1997). Organizational memory information systems: Characteristics and development strategies. In proceedings of the 30th Annual Hawaii International Conference on System Sciences.

Nelson, R., \& Winter, S. (1982). An evolutionary theory of economic change. Cambridge: Belknap Press/Harvard University Press.

Noe, R. A., Hollenbeck, J. R., Gerhart, B. \& Wright, P.M. (2006).Human resource management, (5th Ed.) New York: McGraw-Hill.

Nonaka, I. (1994). A dynamic theory of organizational knowledge creation. Organization Science, 5(1), 14-37.

Nonaka, I. \& Takeuchi, H. (1995).The knowledge-creating company: How Japanese companies create the dynamics of innovation. New York: Oxford University Press.

Nooteboom, B., Van Haverbeke, W., Duysters, G., Gilsing, V., \& Van de Oord, A. (2007). Optimal cognitive distance and absorptive capacity. Research Policy, 36(7), 10161034.

Nutt, P. C. (1976). Models of decision making in organizations and some contextual variables which stipulate optimal use. Academy of Management Review, 1(2 (April 1976)), 8498 .

Obikeze, S. O. (2005). Personnel Management. Onitsha: Book Point Ltd.

Oduoza, C.F., (2010). Decision support system based on effective knowledge management framework to process customer order enquiry, UK.

Pacharapha, T., \& Ractham, V. V. (2012). Knowledge acquisition: The roles of perceived value of knowledge content and source. Journal of Knowledge Management, 16(5), 724-739.

Paprika, Z.Z., (2001). Knowledge management support in decision making. Budapest, Hungary Publishers Ltd. 
Patterson, W., \& Ambrosini, V. (2015). Configuring absorptive capacity as a key process for research intensive firms. Technovation, 36(37), 77-89.

Payne, J. W., Bettman, J. R., \& Johnson, E. J. (1993). The adaptive decision maker: Cambridge University Press.

Pettigrew, A. (1973). The Politics of Organizational Decision Making: Tavistock.

Pinho, I., Rego, A., \& Cunha, M. P. (2012). Improving knowledge management processes: a hybrid positive approach. Journal of Knowledge Management, 16(2), 215-242.

Polanyi, M. (1964). Personal knowledge: Toward a post-critical philosophy. New York: Harper Torchbooks.

Polanyi, M. (1967). The tacit dimension. London: Routledge \& Kegan Paul Ltd.

Poynder, R. (1998). Getting to the nuts and bolts of knowledge management. Information World Review, 135(20), 135-155.

Polanyi, M. (1967). The tacit dimension. London: Routledge and Keoan Paul.

Poole, M. S., Van de Ven, A. H., Dooley, K., \& Holmes, M. E. (2000). Organizational change and innovation processes. New York: Oxford University Press.

Poynder, R. (1998). Getting to the nuts and bolts of knowledge management. Information World Review, 135(20), 135-155.

Prahalad, C. K., \& Hamel, G. (1990). The core competence of the corporation. Harvard Business Review, 68(3), 3-15.

Robbins, S. P., \& Coulter, M. (2009). Management. New Jersey: Prentice Hall.

Rothaermel, F. T., \& Alexandre, M. T. (2009). Ambidexterity in technology sourcing: The moderating role of absorptive capacity. Organization Science, 20(4), 759-780.

Rowley, J. (2001). Knowledge management in pursuit of learning. The learning with knowledge cycle. Journal of Information Science, 27(4), 227-237.

Rusly, F. H., Sun, P. Y. T., \& Corner, J. (2015). Change readiness: Creating understanding and capability for the knowledge acquisition process. Journal of Knowledge Management, 19(6), 1204-1223.

Sandoe, K, \& Olfman, L., (1992). Anticipating the Mnemonic Shift: Organizational Remembering and Forgetting in 2001. In proceedings of the Thirteenth International Conference on Information Systems, ACM Press.

Sarkindaji, B. D., Hashim, N. A., \& Abdullateef, A. O. (2014). Knowledge management and organizational performance of mobile service firms in Nigeria: A proposed framework. In Information and Knowledge Management 4(11), 88-95). 
Schultze, U., \& Leidner, D. E. (2002). Studying knowledge management in information systems research: discourses and theoretical assumptions. Management Information Systems Quarterly, 26(3), 213-242.

Sheng, M. L., \& Chien, I. (2016). Rethinking organizational learning orientation on radical and incremental innovation in high-tech firms. Journal of Business Research, 69(6), 2302-2308.

Simon, H. A. (1955). A behavioral model of rational choice. Quarterly Journal of Economics, 69(1), 99-118.

Simon, H. A. (1997). Administrative Behaviour (Fourth ed.). New York, NY: The Free Press.

Smallman, C., \& Moore, K. (2010). Process studies of tourists' decision-making. Annals of Tourism Research, 37(2), 397-422.

Spender, J. (1996). Organizational knowledge, learning and memory: Three concepts in search of a theory. Journal of Organizational Change Management, 9(1), 63-78.

Spender, J. C., \& Grant, R. M. (1996). Knowledge and the firm: Overview. Strategic Management Journal, 17(S2), 5-9.

Stein, E. W., \& Zwass, V. (1995). Actualizing organizational memory with information systems. Information Systems Research, 6(2), 85-117.

Sveiby, K. E. (1997). A nova riqueza das organizações: Gerenciando e avaliando patrimônios de conhecimento. Rio de Janeiro: Campus.

Swan, J., Newell, S., Scarbrough, H., \& Hislop, D. (1999). Knowledge management and innovation: networks and networking. Journal of Knowledge Management, 3(4), 262275.

Teece, D. J. (2007). Explicating dynamic capabilities: The nature and microfondations of (sustainable) entreprise performance. Strategic Management Journal, 28(1), 13191350.

Teece, D. J., Pisano, A., \& Shuen, A. (1997). Dynamic capabilities and strategic management. Strategic Management Journal, 18(7), 509-533.

Thompson, M. P. A., \& Walsham, G. (2004). Placing Knowledge management in context. Journal of Management Studies, 41(5), 725-747.

Tichy, Noel M., \&Warren G. Bennis (2007).Judgment: How winning leaders make great calls. New York: Penguin.

Torugsa, N. A., \& O'Donohue, W. (2016). Progress in innovation and knowledge management research: From incremental to transformative innovation. Journal of Business Research, 69(5), 1610-1614. 
Tsoukas, H. (1996). The firm as a distributed knowledge system: a constructionist approach. Strategic Management Journal, 17(1), 11-25.

Van de Ven, A. H. (2007). Engaged scholarship: a guide for organizational and social research. New York: Oxford University Press Inc.

Volberda, H. W., Foss, N. J., \& Lyles, M. A. (2010). Absorbing the concept of absorptive capacity: How to realize its potential in the organization field. Organization Science, 21(4), 931-951.

Von Neumann, J., \& Morgenstern, O. (1944). Theory of games and economic behavior: Princeton University Press.

Vorakulpipat, C., \& Rezgui, Y. (2008). An evolutionary and interpretative perspective to knowledge management. Journal of Knowledge Management, 12(3), 17-34.

Walsh, J. P., \& Ungson, G. R. (1991). Organizational memory. Academy of Management Review, 16(1), 57-91.

Ward J., \& Aurum A. (2004). Knowledge management in software engineering - Describing the process. In proceedings of the @004 Australian Software Engineering Conference (ASWEC'04).

Weber, M. (1947). The theory of social and economic organisation. Glencoe IL: The Free Press.

Wiig, K. M. (2004). People-focused knowledge management how effective decision making leads to corporate success. Amsterdam: Elsevier Butterworth Heinemann.

Yang, J. (2010). The knowledge management strategy and its effect on firm performance: A contingence analysis. International Journal of Production Economics, 125(2), 215223.

Yesufu T. M. (2000). The human factor in national development. Ibadan: Spectrum Books Limited.

Yigitcanlar, T., Baum, S., \& Horton, S. (2007). Attracting and retaining knowledge workers in knowledge cities. Journal of Knowledge Management, 11(5), 6-17.

Yuan, Y. C., Fulk, J., Monge, P. R., \& Contractor, N. (2010). Expertise directory development, shared task interdependence, and strength of communication network ties as multilevel predictors of expertise exchange in transactive memory work groups. Communication Research, 37(1), 20-47.

Zack, M. H. (1999). Managing codified knowledge. Sloan Management Review, 40(4), 4548. 
Journal DOI: www.doi.org/10.46654/RJMP

Vol. 1, Issue 3 (March, 2021) | www.ijaar.org

Article DOI: $\underline{\text { www.doi.org/10.46654/RJMP.1312 }}$

Zenger, Todd R. (1994). Explaining organizational diseconomies of scale in R\&D: Agency problems and the allocation of engineering talent, ideas, and effort by firm size, Management Science, 40 (6), 708-29.

Zollo, M., \& Winter, S. G. (2002). Deliberate learning and the evolution of dynamic capabilities. Organization Science, 13(3), 339-351. 